\title{
Solvothermal Synthesis of Barium Titanate Nanocubes with Narrow Size Distributions
}

\author{
Seiya Amano, Kouichi Nakashima, Shintaro Ueno and Satoshi Wada ${ }^{*}$ \\ Material Science and Technology, Interdisciplinary Graduate School of Medical and Engineering, \\ University of Yamanashi, 4-4-37 Takeda, Kofu, Yamanashi 400-8510, JAPAN \\ * Corresponding author: Fax: 81-55-220-8555, and e-mail: swada@yamanashi.ac.jp
}

\begin{abstract}
Barium titanate $\left(\mathrm{BaTiO}_{3}\right)$ nanocubes were synthesized by solvothermal reaction. The synthesis was performed using barium hydroxide $\left[\mathrm{Ba}(\mathrm{OH})_{2}\right]$, barium acetate $\left[\mathrm{Ba}\left(\mathrm{CH}_{3} \mathrm{COO}\right)_{2}\right]$, and titanium dioxide $\left(\mathrm{TiO}_{2}\right)$ as starting materials, with $\mathrm{Ba} / \mathrm{Ti}$ atomic ratio of 2.0 and Ti concentration of 0.04 $\mathrm{mol} / \mathrm{l}$. A mixture of ethanol, 2-methoxyethernol and water was added to the starting materials and this mixture was heated at $240^{\circ} \mathrm{C}$ for $18 \mathrm{~h}$ in an autoclave. X-ray diffraction measurements confirmed the formation of $\mathrm{BaTiO}_{3}$ with a perovskite structure. The water served as an oxygen source for synthesis $\mathrm{BaTiO}_{3}$. Scanning electron microscopy (SEM) and transmission electron microscopy (TEM) observations revealed cube-shaped $\mathrm{BaTiO}_{3}$. In order to synthesize the small-scale $\mathrm{BaTiO}_{3}$ nanocubes, various reaction conditions such as the amount of water addition, kind of barium source, and amount of barium source were investigated. $\mathrm{BaTiO}_{3}$ nanocubes with sharp-edged corners were formed by increasing the proportion of $\mathrm{Ba}\left(\mathrm{CH}_{3} \mathrm{COO}\right)_{2}$ used as a raw material for the barium source.
\end{abstract}

Key words: $\mathrm{BaTiO}_{3}$, nanocube, solvothermal method, perovskite oxide

\section{Introduction}

Perovskite oxides have an important role in the fabrication of electric devices such as multilayer ceramic capacitors (MLCCs), piezoelectric actuators for micro electro mechanical systems, electro-optics [1]. In recent years, there are strong demands to miniaturize the devices and to enhance electric properties of the constituent components. The miniaturization of these electric devices is reaching a limit because the constituent materials which are synthesized by conventional solid state reaction method are too large to miniaturize these devices. Nowadays, these materials are down-sized by milling process, which is called "top-down" method. However, the materials often undergo chipping and contamination through milling and electric properties can't be optimized. Therefore, it is necessary to establish an entirely-new method for the fabrication of these devices or to create new functional materials in the near future. The "bottom-up" process from nano-sized materials is a key engineering to achieve these demands [2-11]. The assembled and ordered structure prepared from nanocrystallites building blocks is well-known as one of the bottom-up processes. These assemblies have lots of advantages such as high surface area, quantum size effect, and utilization of specific properties which depend on the shape of the nanocrystals as well as the configuration of the nanocrystals assembled structure.

Barium titanate $\left(\mathrm{BaTiO}_{3}, \mathrm{BT}\right)$ and strontium titanate $\left(\mathrm{SrTiO}_{3}, \mathrm{ST}\right)$ are the most popular perovskite oxides for electronic device application such as MLCCs, positive temperature coefficient (PTC) thermistor. Recently, the morphology control of the perovskite oxide such as BT was studied with a liquid phase reaction in order to fabricate functional materials. In particular, nanocubes has been attractive attention in the field of electroceramic materials. It has been reported that BT/ST artificial superlattice thin film which consists of a few unit cells per layer has ferroelectricity and enhanced dielectric properties [12-13]. The origin of these high dielectric and ferroelectric properties in the superlattices is traced to the lattice strain which is induced at the hetero-interfaces due to lattice mismatch such as BT/ST interfaces. In other words, hetero-interface is key point for the electroceramic materials. Checkerboard structure which is built by nanocubes has many hetero-interfaces, so that improvement of physical properties further can be expected in the field of electroceramic materials [14-18]. For this purpose, be synthesis nanocubes with narrow particle size distribution is required, and to continue with the synthesis of BT nanocubes in this study [7-8]. We have focused on the interface of nanocubes with perovskite oxides in order to develop electroceramic materials. The interface of particles is a very important factor in development of enhanced materials. It is necessary for the interface of nanocubes to be bare, so we do not use dispersants or surfactants when synthesizing nanocubes. In this study, synthesis of $\mathrm{BaTiO}_{3}$ nanocubes was investigated by solvothermal method. In particular, raw materials were examined in order to obtain $\mathrm{BaTiO}_{3}$ nanocubes.

\section{Experimental Method}

First of all, water was used at solvothermal reaction as reaction medium. BT was prepared by the solvothermal method. As raw materials, $20 \mathrm{mmol} \mathrm{Ba}(\mathrm{OH})_{2}$ (Ube Materials Industries Co., Ltd.; > 99.9\%) and $10 \mathrm{mmol}$ $\mathrm{TiO}_{2}$ (Ishihara Co., Ltd.) $(\mathrm{Ba}: \mathrm{Ti}=2.0)$ were added into mixed solvent $(150 \mathrm{ml}$ of ethanol and $100 \mathrm{ml}$ 2-metoxy 
ethanol). The solution was transferred into a $500 \mathrm{ml}$ autoclave, and then $10 \mathrm{ml}$ of distilled water was added into the solution. The sealed autoclave was heated at $240{ }^{\circ} \mathrm{C}$ for $18 \mathrm{~h}$, and then cooled at room temperature. After the synthesis, the precipitate was collected centrifugal separator and washed twice with water and once with ethanol. The product was dried in a dryer $80{ }^{\circ} \mathrm{C}$ overnight. Finally the product was washed to elimination impurity by acetic acid aqueous solution.

Next barium source was chosen less reactive than $\mathrm{Ba}(\mathrm{OH})_{2} . \mathrm{BaCO}_{3}, \mathrm{BaC}_{2} \mathrm{O}_{4}$ and $\mathrm{Ba}\left(\mathrm{CH}_{3} \mathrm{COO}\right)_{2}$ were chosen as the barium source candidates. As raw materials, $1 \mathrm{mmol}$ barium source and $0.25 \mathrm{mmol} \mathrm{TiO}_{2}$ (Ishihara Co., Ltd.) $(\mathrm{Ba}: \mathrm{Ti}=4.0)$ were added into 12.5 $\mathrm{ml} 0.08 \mathrm{M} \mathrm{KOH}$ aqueous solution. The solution was transferred into a $25 \mathrm{ml}$ autoclave. The sealed autoclave was heated at $230{ }^{\circ} \mathrm{C}$ for $18 \mathrm{~h}$, and then cooled at room temperature. After the synthesis, the precipitate was collected centrifugal separator and washed twice with water and once with ethanol. The product was dried in a dryer $80{ }^{\circ} \mathrm{C}$ overnight. Finally the product was washed to elimination impurity by acetic acid aqueous solution.

BT was synthesised to mix barium source $\left(\mathrm{Ba}(\mathrm{OH})_{2}\right.$ and $\left.\mathrm{Ba}\left(\mathrm{CH}_{3} \mathrm{COO}\right)_{2}\right)$. As raw materials, $(20-\mathrm{x}) \mathrm{mmol}$ $\mathrm{Ba}(\mathrm{OH})_{2}$ (Ube Materials Industries Co., Ltd.; > 99.9\%), x mmol $\mathrm{Ba}\left(\mathrm{CH}_{3} \mathrm{COO}\right)_{2}$ (Kanto Chemical Co., Ltd.; > $99.0 \%$ ) and $10 \mathrm{mmol} \mathrm{TiO}_{2}$ (Ishihara Co., Ltd.) (Ba : Ti $=2.0)$ were added into mixed solvent $(150 \mathrm{ml}$ of ethanol and $100 \mathrm{ml}$ 2-metoxy ethanol). The solution was transferred into a $500 \mathrm{ml}$ autoclave, and then $10 \mathrm{ml}$ of distilled water was added into the solution. The sealed autoclave was heated at $240{ }^{\circ} \mathrm{C}$ for $18 \mathrm{~h}$, and then cooled at room temperature. After the synthesis, the precipitate was collected centrifugal separator and washed twice with water and once with ethanol. The product was dried in a dryer $80{ }^{\circ} \mathrm{C}$ overnight. Finally the product was washed to elimination impurity by acetic acid aqueous solution.

\section{Results and Discussion}

Figure 1 shows XRD pattern and SEM images of the product obtained in the synthesis with the solutions containing various amounts of water. Reduction in peak of $\mathrm{TiO}_{2}$ could be confirmed from the result of XRD pattern, it is gradually increased the amount of water added, it was confirmed single phase BT in the system was added $10 \mathrm{ml}$ of water. However, it was supposed to form the particles is like as spherical by SEM observation. $\mathrm{TiO}_{2}$ was completely dissolved in the solvent solubility is increased by adding water to the solvent, $\mathrm{TiO}_{2}$ is easily dissolved, and $10 \mathrm{ml}$ water is added, but with the increase in solubility, nucleation is shifted to the lower temperature side. It is believed that nuclei were formed isotropically due to the shape of the particles and it became spherical.

Figure 2 shows XRD pattern of the product obtained in the synthesis with $\mathrm{BaC}_{2} \mathrm{O}_{4}, \mathrm{BaCO}_{3}$ and $\mathrm{Ba}\left(\mathrm{CH}_{3} \mathrm{COO}\right)_{2}$. From XRD pattern, It was able to confirm that formation of BT only system using a $\mathrm{Ba}\left(\mathrm{CH}_{3} \mathrm{COO}\right)_{2}$ to barium source. Synthesis of BT can't be confirmed in the system of the other, only the peak of the raw material

could be confirmed. That considered BT has not been generated for $\mathrm{BaC}_{2} \mathrm{O}_{4}$ and $\mathrm{BaCO}_{3}$ were not dissolved in the solvent as the cause.
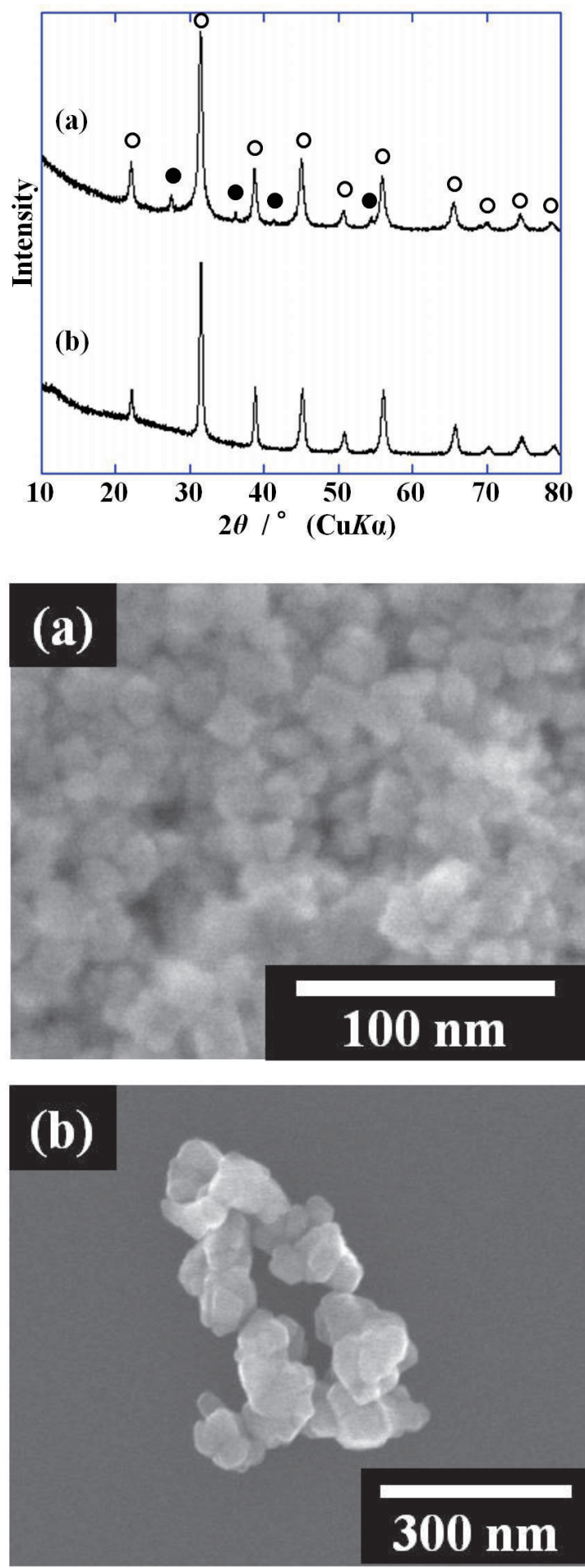

Fig. 1 XRD patterns and SEM images of the obtained BT powder.

$\mathrm{Ba}(\mathrm{OH})_{2}$ : 20 mmol, $\mathrm{TiO}_{2}: 10 \mathrm{mmol}$, Temperature: $240^{\circ} \mathrm{C}$, Time: $18 \mathrm{~h}, \mathrm{H}_{2} \mathrm{O} / \mathrm{ml}$ :

(a) 0 , (b) 10 .

$\bigcirc: \mathrm{BaTiO}_{3}, \mathrm{O}: \mathrm{TiO}_{2}$. 


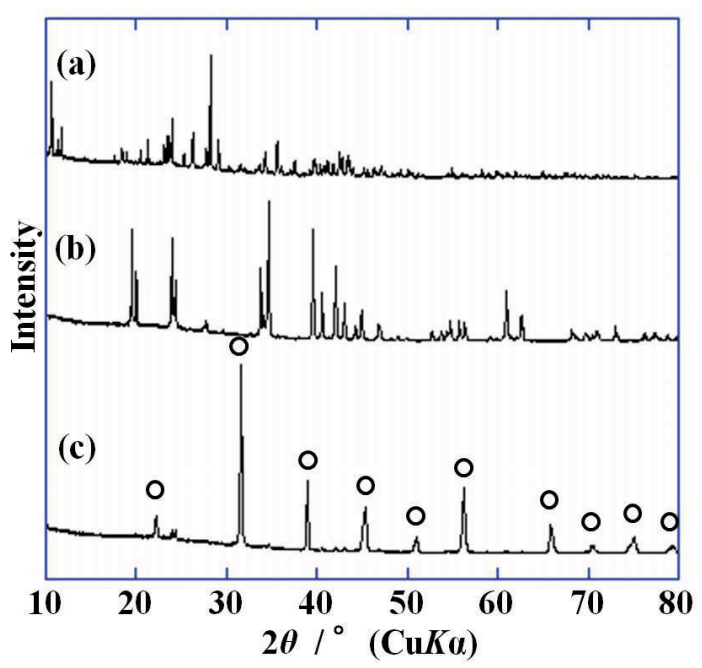

Fig.2 XRD patterns of the obtained BT powder.

$\mathrm{TiO}_{2}: 0.25 \mathrm{mmol}$, Temperature: $230^{\circ} \mathrm{C}$, Time: $18 \mathrm{~h}$, Barium source $(1 \mathrm{mmol})$ : (a) $\mathrm{BaC}_{2} \mathrm{O}_{4}$, (b) $\mathrm{BaCO}_{3}$, (c) $\mathrm{Ba}\left(\mathrm{CH}_{3} \mathrm{COO}\right)_{2}$.

\section{$\bigcirc: \mathrm{BaTiO}_{3}, \mathrm{O}^{\mathrm{TiO}}$.}

Figure 3 shows XRD pattern and SEM images of the product obtained in $\mathrm{BT}$ synthesis with mixture of $\mathrm{Ba}(\mathrm{OH})_{2}$ and $\mathrm{Ba}\left(\mathrm{CH}_{3} \mathrm{COO}\right)_{2}$. From XRD pattern, an increase of the peak of $\mathrm{TiO}_{2}$ was confirmed ratio of $\mathrm{Ba}\left(\mathrm{CH}_{3} \mathrm{COO}\right)_{2}$ to be used for the $\mathrm{Ba}$ source and increases the proportion of $\mathrm{Ba}\left(\mathrm{CH}_{3} \mathrm{COO}\right)_{2}$ in the system of more than $50 \%$. Ratio of $\mathrm{Ba}\left(\mathrm{CH}_{3} \mathrm{COO}\right)_{2}$ was confirmed a single phase of BT in the system of $40 \%$ or less. The ratio of $\mathrm{Ba}\left(\mathrm{CH}_{3} \mathrm{COO}\right)_{2}$ could be observed spherical particles in the system of more than $20 \%$ from the SEM, it was possible to observe the particles cubes in the system of more than $40 \%$. The ratio of $\mathrm{Ba}\left(\mathrm{CH}_{3} \mathrm{COO}\right)_{2}$ which could be observed particles cubes and $\mathrm{BT}$ single phase was observed by TEM systems $40 \%$. The observations was shown in Fig. 4 . It is a single crystal and suggested that the presence of particles particles cubes can be confirmed on the whole, was obtained by the electron diffraction pattern in the range of (c) from (d). It can see from these results, the shape of the particles obtained as the ratio of $\mathrm{Ba}\left(\mathrm{CH}_{3} \mathrm{COO}\right)_{2}$ to be used for the barium source is increased is likely to be a cube shape, the titanium oxide is less soluble as the ratio of $\mathrm{Ba}\left(\mathrm{CH}_{3} \mathrm{COO}\right)_{2}$ is increased, which results it is believed to be due to the nucleation, nucleus growth is shifted to the high temperature side, the crystal growth occurred more regularly.

\section{Conclusions}

BT nanoparticles single phase were prepared using a solvothermal reaction at $240{ }^{\circ} \mathrm{C}$ for $18 \mathrm{~h}$ from solutions containing various amounts of water. Water was identified to be important for the dissolution for $\mathrm{TiO}_{2}$. Furthermore, a new approach based on a mixture of raw materials as barium sources was investigated. BT nanocubes were successfully prepared using this approach and solvothermal reaction at $240{ }^{\circ} \mathrm{C}$ for $18 \mathrm{~h}$. with $\mathrm{Ba}(\mathrm{OH})_{2}$ and $\mathrm{Ba}\left(\mathrm{CH}_{3} \mathrm{COO}\right)_{2}$ as barium source. The size of $\mathrm{BT}$
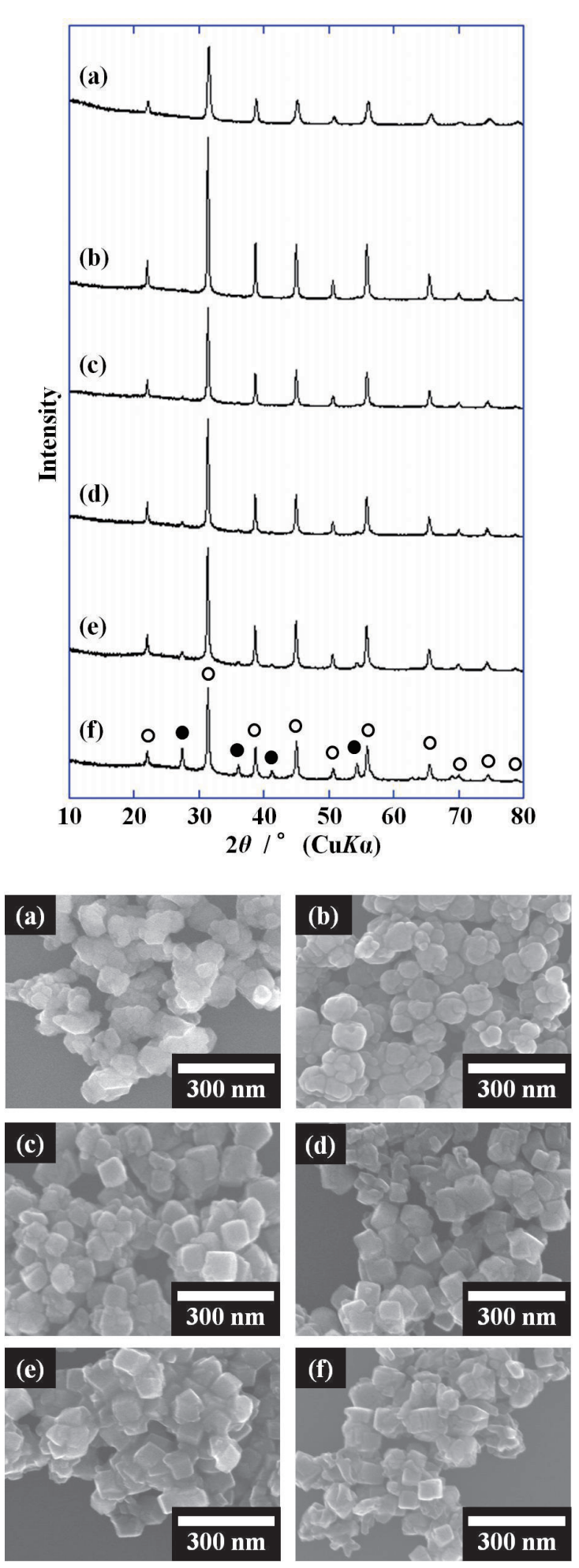

Fig.3 XRD patterns and SEM images of the obtained BT powder.

$\mathrm{TiO}_{2}: 10 \mathrm{mmol}$, Temperature: $240^{\circ} \mathrm{C}$, Time: $18 \mathrm{~h}$, $\mathrm{Ba}(\mathrm{OH})_{2} / \mathrm{mmol}$, (a) 20, (b) 16 , (c) 12 , (d) 10 , (e) 8 , (f) $4, \mathrm{Ba}\left(\mathrm{CH}_{3} \mathrm{COO}\right)_{2} / \mathrm{mmol}$, (a) 0, (b) 4 , (c) 8, ,d) 10 , (e) 12 , (f) 16 .

$\bigcirc: \mathrm{BaTiO}_{3}, \quad$ : $\mathrm{TiO}_{2}$. 

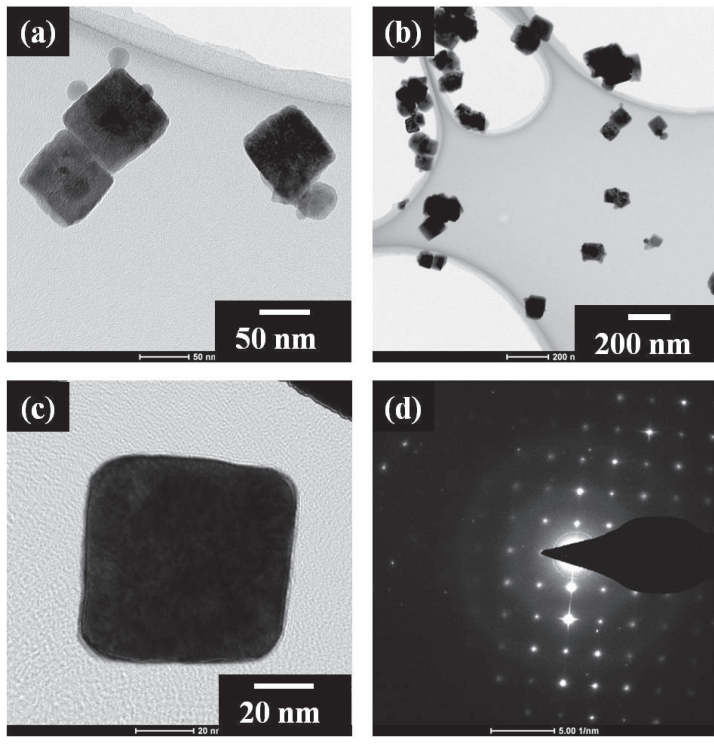

Fig.4 TEM images of the obtained BT powder.

$\mathrm{TiO}_{2}: 10 \mathrm{mmol}$, Temperature: $240^{\circ} \mathrm{C}$, Time: $18 \mathrm{~h}$, $\mathrm{Ba}(\mathrm{OH})_{2}: 12 \mathrm{mmol}, \mathrm{Ba}\left(\mathrm{CH}_{3} \mathrm{COO}\right)_{2}: 8$ mmol. (a) and (b) Bright-field TEM images, (c) Selected-area bright-field TEM image and (d) its selected-area electron diffraction image.

particles increases with the $\mathrm{Ba}\left(\mathrm{CH}_{3} \mathrm{COO}\right)_{2}$ concentration, suggesting the nucleation rate of BT decreased with the $\mathrm{Ba}\left(\mathrm{CH}_{3} \mathrm{COO}\right)_{2}$ concentration. $\mathrm{Ba}\left(\mathrm{CH}_{3} \mathrm{COO}\right)_{2}$ could have a role of generating nuclei of nanocubes and $\mathrm{Ba}(\mathrm{OH})_{2}$ could have a role of growing nanocubes. The proposed technique allowed for shape control in the present study, and prepared BT nanocubes that may enable the creation of new electroceramic materials with enhanced properties.

Acknowledgment

The authors would like to express their gratitude to Ube Materials Industries Co., Ltd., for providing us with $\mathrm{Ba}(\mathrm{OH})_{2}$ as a raw material.
References

[1] K. Mimura, F. Dang, K. Kato, H. Imai, S. Wada, H. Haneda, and M. Kuwabara, Journal of Nanoscience and Nanotechnology, 12, 3853-3861 (2012).

[2] K. Nakashima, I. Fujii, S. Wada, Journal of the Ceramic Society of Japan, 119, 532-535 (2011).

[3] K. Nakashima, I. Fujii, S. Wada, Journal of the Society of Inorganic Materials, Japan, 19, 97-103 (2012).

[4] K. Nakashima, I. Fujii, S. Wada, Journal of the Ceramic Society of Japan, 121, 693-697 (2013).

[5] K. Nakashima, I. Fujii, S. Wada, Journal of Crystal Growth, 376, 35-40 (2013).

[6] K. Nakashima, M. Kera, I. Fujii, S. Wada, Ceramics International, 39, 3231-3234 (2013).

[7] F. Dang, K. Mimura, K. Kato, H. Imai, S. Wada, H. Haneda and M. Kuwabara, CrystEngComm., 13, 3878-3883 (2011).

[8] F. Dang, K. Mimura, K. Kato, H. Imai, S. Wada, H. Haneda, and M. Kuwabara, Nanoscale 4, 1344-1349 (2012).

[9] K. Fujinami, K. Katagiri, J. Kamiya, T. Hamanaka, K. Koumoto, Nanoscale, 2, 2080-2083 (2010).

[10] M. Niederberger, G. Garnweitner, N. Pinna, and M. Antonietti, Journal of the Amrican Chemical Society, 126, 9120-9126 (2004).

[11] C. H. Ahn, K. M. Rabe, J.-M. Triscone, Science, 303, 488-491 (2004).

[12] T. Tsurumi, T. Harigai, D. Tanaka, H. Kakemoto, and S. Wada, Sci. Technol. Adv. Mater., 5, 425-429 (2004).

[13] A. Q. Jiang, J. F. Scott, H. Lu, and Z. Chen, Journal of Applied Physics., 93, 1180 (2003).

[14] K. Mimura, F. Dang, K. Kato, H. Imai, S. Wada, H. Haneda, and M. Kuwabara, Japanese Journal of Applied Physics, 50, 09NC09 (2011).

[15] K. Mimura,K. Kato, H. Imai, S. Wada, H. Haneda and M. Kuwabara, Applied Physics Letters, 101, 012901 (2012).

[16] K. Mimura, F. Dang, K. Kato, H. Imai, S. Wada, H. Haneda and M. Kuwabara, Key Engineering Materials, 566, 285-288 (2013).

[17] A. Nozawa, T. Kuwabara, H. Uchida, C. Moriyoshi, Y. Kuroiwa, Key Engineering Materials, 421, 514-517 (2010) .

[18] S. Wada, A. Nozawa, M. Ohno, T. Tsurumi and Y. Kuroiwa, Key Engineering Materials, 388, 111-114 (2008).

(Received January 17, 2014; Accepted March 14, 2014) 